\title{
The Socioeconomic Position of Pakistan in the Third World
}

\author{
M. H. KHAN and J. A. ZERBY*
}

\begin{abstract}
A number of social and economic indices are constructed by utilising a total of 120 variables to compare Pakistan with 96 other developing countries of Asia, Africa and Latin America. These countries are ranked on scales of these indices by using the Wroclaw Taxonomic Method and are grouped on the basis of similarities with the help of a clustering technique. Pakistan seems to have achieved a reasonable degree of success in both social and economic areas but her performance in the latter is more pronounced.
\end{abstract}

\section{INTRODUCTION}

Economists and politicians often compare their particular countries with other countries at similar levels of development as a preliminary step in setting future growth targets. The realisation of the goals depends upon the supply of available resources and the efficiency with which they are combined. Comparative analyses can contribute only modestly to this ultimate objective, but, nevertheless, they can assist greatly in directing attention towards specific areas in which a comparative deficiency exists and in establishing a degree of reasonableness to the targets. A number of sophisticated statistical techniques - such as factor analysis, discriminant analysis, canonical correlation, multiple regression $[1 ; 2 ; 3 ; 4 ; 5 ; 7]$ - have so far been applied to cross-country comparisons. Many of these techniques require $a$ priori judgments of causal relationships, ${ }^{1}$ and it is a well-known fact that development is a process of interaction among great many socioeconomic variables, none of

*The authors are, respectively, Associate Professor of Economics at Jahangirnagar University, Dacca (Bangladesh) and Senior Lecturer of Econometrics at the University of New South Wales, Sydney (Australia). They wish to acknowledge the assistance of the Division of Computing Research of the Commonwealth Scientific and Industrial Research Organization, Canberra (Australia) for the use of their clustering programmes. The Wroclaw Taxonomic Analysis Program was obtained from the Princeton University. The authors are grateful to an unknown referee for his valuable comments on an earlier draft of this paper.

${ }^{1}$ Factor analysis requires specification of a model through which observed factors are 'explained' by a small number of unobserved, latent factors; discriminant analysis and canonical correlation require a set of preselected groups; and regression analysis requires the specification of a set of fixed, explanatory variables. 
which can be unambiguously treated as functionally 'dependent' or 'independent'. The purpose of this paper is to demonstrate the use of some new techniques which are free from regression elements and thus to make comparative studies more meaningful.

The concept of 'development' is here understood in an integrated socioeconomic sense, using a large number of indicators that cover various aspects of economic and social life rather than "isolated use of individual indicators ... whether the so-called 'economic' indicators, such as GNP, or the so-called 'social' indicators, such as enrolment rates" $[18$, p. 5]. A staff study by the U. N. Research Institute for Social Development under the direction of Donald McGranahan [14], for instance, measured development in terms of 73 socioeconomic indicators from 10 major areas. For the present purpose, this was extended to 120 indicators, representing six social and six economic categories as shown in Table bellow:

\section{Social and Economic Indicators}

\section{Social Indicators}

Demographic

Health and Nutrition

Education

Housing

Cultural

Political

\section{Composite Social Index}

\section{Economic Indicators}

\section{Agricultural}

Industrial

Labour

Transport and Communications

International Trade

General Economic

Composite Economic Index

\section{Number of Indicators}

$\begin{array}{r}13 \\ 12 \\ 20 \\ 7 \\ 8 \\ 6 \\ \hline\end{array}$

6

\section{7}

6

14

11

10

54
In addition to the separate composite social and economic indices, an aggregate index of socioeconomic development, comprising all the 120 indicators, was also constructed.

In this paper, we compare the position of Pakistan with respect to other members of the Third World on scales of the above-mentioned indices of development. A total of 97 countries ( 32 from Asia and Pacific, 41 from Africa and 24 from
Latin America) are included in our definition of the Third World countries (see Appendix Table 1 for the complete list of countries). The numerical procedures are briefly described in Section II. The results are given in Section III and the conclusions are stated in Section IV, which also includes a discussion on the usefulness of such comparative studies.

\section{METHODOLOGY AND DATA}

Two separate procedures are used in the analysis. The first relates to a ranking of the countries on he basis of selected indicators. For this purpose, we used a variation of the Wroclaw Taxonomic Method which was developed in the early 1950s by a group of Polish mathematicians and has had several applications to development studies $[8 ; 11 ; 17 ; 19]$. The second procedure involves the grouping of countries according to the degree of similarity within groups relative to that between groups. We shall refer to the latter procedure as cluster analysis $[6 ; 16]$.

The ranking procedure starts with the standardised (zero mean and unit variance) data matrix of the following type (for ' $N$ ' countries and ' $n$ ' variables):

$$
\left[\begin{array}{l}
\tilde{x}_{11} \\
\tilde{x}_{21} \\
\tilde{x}_{N 1}
\end{array}\right.
$$$$
\left.\begin{array}{l}
\tilde{\mathrm{x}}_{12} \ldots \ldots \ldots \tilde{\mathrm{x}}_{1 \mathrm{n}} \\
\tilde{\mathrm{x}}_{22} \ldots \ldots \ldots \tilde{\mathrm{x}}_{2 \mathrm{n}} \\
\tilde{\mathrm{x}}_{\mathrm{N} 2} \ldots \ldots \mathrm{x}_{\mathrm{Nn}}
\end{array}\right] \ldots
$$$$
\cdots
$$

Using this matrix, one may rank countries according to their performances in any specific area of development. Assumptions must be made as to whether a particular indicator is a stimulant (positive factor) or a retardant (negative factor) to development. An 'ideal' country is chosen on the basis of the 'best' values for each indicator. The difference between the 'ideal' country (country ' $\mathrm{H}$ ) and any observed country is termed the 'Pattern of Development' (P.D.) and is generally measured on the basis of Euclidean distance:

$$
\begin{gathered}
(\text { P.D. })_{i H}=\left[\sum_{j=1}^{n}\left(\tilde{x}_{i j}-\tilde{x}_{H j}\right)^{2}\right]^{1 / 2} \quad \ldots \\
i=1,2, \ldots \ldots N
\end{gathered}
$$

An alternative measure of distance from the 'ideal' country is termed the 'Measure of Development' (M.D.), which is obtained by normalising the P.D. so that its value ranges between 0.0 (for the most developed country) and 1.0 (for the least developed 
country). The 'critical' distance from the 'ideal' country is generally used as the normaliser. The calculation involves the following:

$$
\text { (M.D. })_{\mathrm{i}}=\frac{(\text { P.D. })_{\mathrm{iH}}}{\mathrm{C}_{\mathrm{H}}} \quad \ldots . . .
$$

where

$\mathrm{C}_{\mathrm{H}}=$ 'Critical' distance from the 'ideal' country

$$
\left.=\frac{1}{\mathrm{~N}} \sum_{\mathrm{i}=1}^{\mathrm{N}}(\text { (P.D. })_{\mathrm{iH}}+2\left[\frac{1}{\mathrm{~N}} \sum_{\mathrm{i}=1}^{\mathrm{N}}\left\{(\text { P.D. })_{\mathrm{iH}}-\frac{1}{\mathrm{~N}} \sum_{\mathrm{i}=1}^{\mathrm{N}} \quad \text { (P.D. }\right)_{\mathrm{iH}}\right\}^{2}\right]^{1 / 2}
$$

In addition to rank-ordering, the method can also be used for producing country 'clusters' on the basis of similarities. Using the standardised data matrix, it is possible to calculate the Euclidean distances from one country to every other country, which produces a symmetric matrix known as the 'distance matrix'. From the latter, it is possible to obtain the 'primary', 'secondary' and 'tertiary' models (the first three closest neighbours) for each country. A hierarchical clustering of countries can then be generated by drawing a 'single-joint' graph. However, somewhat more sophisticated clustering techniques are currently available with the Division of Computing Research, C.S.I.R.O., Australia [15]. These programmes not only provide the user with the appropriate number of groups but also show the contribution of various indicators in successive group formations through their 'diagnostic' routine. We have recently demonstrated how these programmes can effectively be used in development studies $[10 ; 11 ; 12 ; 13 ; 20]$.

Data for the selected countries are taken from a data bank, compiled by one of the authors [9], which contains post-1970 (mostly 1974-75) statistics for 120 indicators. (See Appendix Table 2 for the complete list covering a wide range of countries.) These data are largely derived from various national and international sources. Some observations were missing and, therefore, had to be estimated by calculating the appropriate group averages with the use of cluster analysis.

\section{EMPIRICAL FINDINGS}

The Wroclaw Taxonomic analysis programme ${ }^{2}$ was run separately for all social, economic and socioeconomic indices of development. ${ }^{3}$ Table 1 shows the position of Pakistan on the seven social indices of development within the group of

${ }^{2}$ The programme is called PRINTAX and is at present held in slightly modified form by the computing services unit, the University of New South Wales, in a file named CLUSEXX.

3 A few socioeconomic indicators such as crude death rates, infant mortality rates, deaths from political violence, general level of unemployment, degree of industrial unrest, export concentration index, Gini index of income inequality, etc., are considered 'negative' factors to development. For details, see Khan $[10 ; 11]$.
Table 1

\begin{tabular}{|c|c|c|c|c|c|c|}
\hline \multirow{3}{*}{ Index } & \multicolumn{5}{|c|}{ Range of (M.D.) } & \multirow{3}{*}{$\begin{array}{c}\text { Rank } \\
\text { of } \\
\text { Pakistan }\end{array}$} \\
\hline & \multicolumn{2}{|c|}{ Highest } & \multicolumn{2}{|c|}{ Lowest } & \multirow{2}{*}{ Pakistan } & \\
\hline & Value & Country & Value & Country & & \\
\hline Demographic & 0.5019 & Hongkong & 1.0000 & Kuwait & 0.8443 & $42 n d$ \\
\hline Health \& Nutrition & 0.2292 & Israel & 0.9171 & Bangladesh & 0.8287 & 68 th \\
\hline Education & 0.5044 & Israel & 0.9973 & Chad & 0.9158 & 85 th \\
\hline Housing & 0.4204 & Hongkong & 1.0000 & Bangladesh & 0.8850 & $91 \mathrm{st}$ \\
\hline Culture & 0.4304 & Israel & 0.8811 & Ethiopia & 0.8496 & $63 \mathrm{rd}$ \\
\hline Politics & 0.2363 & Madagascar & 1.0000 & Israel & 0.7939 & $73 \mathrm{rd}$ \\
\hline Composite Social & 0.6354 & Israel & 0.9358 & Bangladesh & 0.8941 & 84th \\
\hline
\end{tabular}

The Social Status of Pakistan in the Third World

97 developing countries. It also shows the range of M.D. (i.e. Measure of Develop ment) for different indices. Pakistan is relatively more developed in the demographic, cultural and health-nutritional indices, while she is less developed in housing, education and political areas. As a whole, on the composite social scale, she occupies 84 th position in the third world. Within Asia (32 countries including Fiji and Papua New Guniea), Pakistan seems to have a reasonably good status having 21 st position in the composite index (Appendix Table 1). There is a considerable amount of variation among the selected social indicators (as is evident from the first two columns of Table 1); the variation is maximum in political data. The highest country is far away from the 'ideal' point in all cases showing that no one country in the developing world occupies 'best' position in all social aspects. Table 2 shows the relative position of Pakistan on various economic indices within the Third World countries. Pakistan shows significant progress in all economic areas except labour. In the composite index, she has a sound economic status in the Third World. Within Asia, Pakistan occupies 18th position (Appendix Table 1) on the combined scale. There is significant variation among all economic indicators and the highest country is far off from the ideal country. In the aggregate socioeconomic index of development, Pakistan seems to occupy a comfortable position in the Third World (with a measure of 0.9020 and 71 st rank in order of merit). It is important to note that Pakistan has the strongest position in the South Asian subcontinent in terms of overall socioeconomic achievements. The results of Table 3 demonstrate the argument. Although India has fared relatively well in social sectors, Pakistan's spectacular development in economic areas more than outweighs India's social gains; and in the aggregate socioeconomic index, Pakistan emerges as the 
'champion' in the subcontinent. Besides India and Bangladesh, a few other Asian countries - Burma, Laos, Dem. Kampuchea, Afghanistan, Vietnam S.R., Yemen A. R., and Nepal are also ranked below Pakistan in the aggregate scale (Appendix Table 1).

Table 2

The Economic Status of Pakistan in the Third World

\begin{tabular}{|c|c|c|c|c|c|c|}
\hline \multirow{3}{*}{ Index } & \multicolumn{5}{|c|}{ Range of (M.D.) } & \multirow{3}{*}{$\begin{array}{c}\text { Rank } \\
\text { of } \\
\text { Pakista }\end{array}$} \\
\hline & \multicolumn{2}{|c|}{ Highest } & \multicolumn{2}{|c|}{ Lowest } & \multirow{2}{*}{ Pakistan } & \\
\hline & Value & Country & Value & Country & & \\
\hline Agriculture & 0.3987 & Singapore & 0.9711 & Kampuchea & 0.8656 & 48th \\
\hline Industry & 0.5149 & Kuwait & 0.9446 & Yemen A.R. & 0.8587 & 56th \\
\hline Labour & 0.3791 & Hongkong & 1.0000 & Guyana & 0.8736 & 87th \\
\hline $\begin{array}{l}\text { Transport \& Commu- } \\
\text { nications }\end{array}$ & 0.6620 & Kuwait & 0.9366 & Nepal & 0.8906 & 57 th \\
\hline International trade & 0.5715 & Singapore & 1.0000 & Vietnam & 0.8435 & 37th \\
\hline General economic & 0.6098 & Libya & 1.0000 & Chile & 0.8855 & 38th \\
\hline Composite economic & 0.7886 & Singapore & 0.9739 & Vietnam & 0.9312 & 59th \\
\hline
\end{tabular}

Table 3

The Position of Pakistan in the South Asian Sub-continent

\begin{tabular}{|c|c|c|c|c|c|c|}
\hline \multirow{2}{*}{ Countries } & \multicolumn{2}{|c|}{ Social } & \multicolumn{2}{|c|}{ Economic } & \multicolumn{2}{|c|}{ Socioeconomic } \\
\hline & $(\mathrm{MD})_{\mathrm{s}}$ & Rank & $(\mathrm{MD})_{\mathrm{e}}$ & Rank & $(\mathrm{MD})_{\mathrm{se}}$ & Rank \\
\hline Pakistan & 0.8941 & 84th & 0.9312 & 59th & 0.9020 & 71st \\
\hline India & 0.8823 & 72nd & 0.9411 & 74th & 0.9057 & 75 th \\
\hline Bangladesh & 0.9358 & 97th & 0.9690 & 94th & 0.9520 & 96th \\
\hline
\end{tabular}

The position of a country varies not only with respect to its measure (i.e. distance from the 'ideal' country) but also in its closeness to other countries (i.e. Euclidean distance from each other). The correct position of a country should only be determined by comparing its rank (based on measure) with clustering (based on closeness) because similar countries may have significantly different rankings and vice versa. Table 4 shows the first three closest neighbours (primary, secondary and tertiary models) of Pakistan in the developing world on three composite indices.
Table 4

Model Countries for Pakistan on Aggregate Indices

\begin{tabular}{|c|c|c|c|c|}
\hline Index & Primary & Secondary & Tertia & \\
\hline Social & India $(4.4388)$ & (4.9006) & Morocco & $(5.0952)$ \\
\hline Economic & India (3.3449) & Guatemala (3.4584) & El Salvador & (4.2714) \\
\hline Socioeconomic & India $(5.7808)$ & Morocco (6.9747) & Sudan & (7.2308) \\
\hline
\end{tabular}

Note: Values in parentheses are actual distances measured to four-decimal figures.

India appears to be the primary model for Pakistan in terms of overall similarities although the two countries are reasonably apart from each other in terms of rank; orderings. The other closest neighbours of Pakistan such as Guatemala and El Salvador are not also very close in terms of ranking score. It must be emphasised that the observed similarity is based upon all 54 economic indicators with equal weight given to each (and no indicators are assumed to be 'retardant' to economic development). It does not mean that the same degree of similarity will exist for any specific indicator (such as GNP per capita or energy consumption per capita) or that the economic structure as a whole may be regarded as identical for two 'closeneighbour' countries. It implies only that the economic structure as depicted by the 54 indicators for Pakistan is more similar to that of Guatemala than to that of any other country except India. Such 'closeness' however, should not be treated lightly. The analysis tends to turn up cross-country comparisons which might otherwise be entirely overlooked. Pakistan's next closest countries, such as Indonesia, Malaysia, Sri Lanka, Thailand, Algeria, Tunisia, Nigeria, etc., are sorted out in the following results of a clustering programme. Table 5 gives a listing of country groups which are more or less similar to Pakistan in terms of three composite indices of development.

It is clear from the clustering results that Pakistan, in general, is more similar to the African developing countries than to the countries of her own region. She is relatively better off in terms of economic indicators and is more or less at the same stage as some North and South American countries, like Bolivia, Brazil, Colombia, Costa Rica, Cuba, Dominican Republic, Ecuador, El Salvador, Guatemala, Honduras, Mexico, Nicaragua, Paraguay and Peru besides some mildly developed countries of Asia and Africa. Bangladesh is completely separated out from Pakistan on aggregate economic scale and this proves that the difference between the two countries is significant in terms of this composite index. However, in terms of total development, both the countries are in the same group and are obviously at an early stage of development (average measure of socioeconomic development for this group is 0.9050 ). 
Table 5

Clusters of Countries Similar to Pakistan

Social Clustering

(49 Countries)
Afghanistan, Algeria, Angola, Bangladesh, Benin, Botswana, Burundi, Cameroon, Central African Republic, Chad, Congo, Ethiopia, Gabon, Gambia, Ghana, Guinea, Haiti, India, Indonesia, Ivory Coast, Kampuchea, Kenya, Laos, Lesotho, Liberia, Madagascar, Malawi, Mali, Mauritania, Morocco, Mozambique, Nepal, Niger, Nigeria, Papua New Guinea, Rwanda, Senegal, Sierra Leone, Somalia, Sudan, Tanzania, Togo, Tunisia, Uganda, Upper Volta, Yemen A. R., Yemen P.D.R., Zaire, Zambia.
Economic Clustering Albania, Algeria, Angola, Benin, Bolivia, Brazil, Cameroon, (57 Countries)

Central African Republic, Colombia, Congo, Costa Rica, Cuba, Dominican Republic, Ecuador, Egypt, El Salvador, Fiji, Gambia, Ghana, Guatemala, Honduras, India, Indonesia, Ivory Coast, Jordan, Kenya, Korea R., Laos, Lesotho, Liberia, Malaysia, Madagascar, Malawi, Mauritania, Mauritius, Mexico, Mongolia, Morocco, Mozambique, Nicaragua, Nigeria, Paraguay, Peru, Philippines, Senegal, Sierra Leone, Sri Lanka, Sudan, Syria, Tanzania, Thailand, Togo, Tunisia, Turkey, Uganda, Yemen P.D.R., Zaire.

Socioeconomic Clustering (48 Countries)
Afghanistan, Angola, Bangladesh, Benin, Bolivia, Botswana, Burundi, Cameroon, Central African Republic, Chad, Congo, Ethiopia, Gabon, Gambia, Ghana, Guinea, Haiti, India, Indonesia, Ivory Coast, Kampuchea, Kenya, Laos, Lesotho, Liberia, Madagascar, Malawi, Mali, Mauritania, Morocco, Mozambique, Nepal, Niger, Nigeria, Papua New Guinea, Rwanda, Senegal, Sierra Leone, Somalia, Sudan, Tanzania, Togo, Tunisia, Uganda, Upper Volta, Yemen A.R., Zaire, Zambia.

\section{EVALUATION AND CONCLUSIONS}

Both clustering and ranking procedures represent an analysis of multivariate interdependence based upon an aggregate measure of the distance between develop ing countries in the sample space which is defined by the numeric values of the selected socioeconomic indicators. The choice of indicators is therefore importan to the procedures and may, in certain cases, be crucial to the results. In this study an attempt was made to include as many indicators as possible, in order to minimize the sensitivity of the results to small changes in the values of the individual indicators, or to slight alterations in the list of indicators.

There are, however, two important limitations to the procedures which should be noted. First of all, the problem of collinearity is not eliminated, so that a high correlation between specific indicators precludes the possibility of assessing the individual effects of the collinear variables. Additionally, the existence of high correlation may overstate the degree of homogeneity, relative to that obtained with a more balanced set of indicators. Secondly, all indicators have been treated equally in the sense that the indicators were not weighted in order of a priori importance. As a consequence, indicators such as the number of cinema seats per capita, which in themselves generate realtively little development ascendancy, are compared on the same basis as the more fully recognised stimulants, such as the annual growth rate of exports.

Notwithstanding the limitations, the analysis provides useful information concerning the socioeconomic structure of Pakistan and indicates some policy prescriptions for her future development. The salient features of Pakistan's socioeconomic performance are as follows. She is relatively better off in economic than in social indices but as a whole her social and economic achievements are closely interrelated. Pakistan plays the leading role in the South Asian subcontinent and occupies a respectable position in the Third World on various scales of development. She seems to have more overall similarities with African developing countries than with the countries of her own region. India, Sudan and Morocco are the three closest neighbours of Pakistan in the aggregate index of socioeconomic development.

The results of such cross-country comparisons can be useful in formulating some 'directions' for the future development of Pakistan. For instance, if we consider the reasons why Pakistan is most similar (though not identical) to India, Sudan and Morocco, some policy implications may come out. Although the whole set of 120 socioeconomic indicators contributed to the observed similarity, the cultural (particularly per capita circulation of daily \& non-daily newspapers, consumption of newsprint, annual cinema attendance), educational (literacy rate, first-level enrollment ratio, percentage of females in first, second and third levels, student/teacher ratios at different levels, expenditure for research \& development, etc., in particular), transport \& communications (specifically, percentage of economically active population engaged in transport, storage \& communications, total road 
network per 100 population, civil aviation, etc.) and some general economic indicators (such as government consumption expenditure as percentage of GDP, private final consumption expenditure as percentage of GDP, gross fixed capital formation as percentage of (GDP) weighed more heavily in the similarity measure. Since Pakistan has developed more or less equivalently with the model countries in the areas indicated above, increased attention should be given to other areas (namely, demographic, health \& nutrition, housing, agriculture, industry, labour, trade, etc.) where comparative deficiency exists in order to maintain a uniform standard of development in the years ahead.

The diagnostic routine ${ }^{4}$ of the clustering programme shows that social factors contribute to the extent of 67 percent to the difference between the countries in Pakistan's group and the group of countries at the next higher level of development. This observation implies that social factors, in general, should be given more importance in Pakistan's future planning which was also revealed by the ranking result (where Pakistan was found to be relatively less developed in the social than in the economic indices). Taking all indicators together (and all the countries clustering with Pakistan), it is observed that Pakistan is particularly worse off in death \& infant mortality rates, urbanisation, life expectation, vocational education and secondlevel enrollment ratio, percentage of total population economically active, percentage of females in the economically active population, salaried and wage-earners as percentage of the total active population, general level of unemployment, percentage contribution of manufacturing in GDP, percentage of female literacy, percentage contribution of agriculture in GDP, etc. (listed in descending order of deficiency). The deficiencies in these indicators, if allowed to persist, may retard development progress. Therefore, more resources should be diverted to these sectors for attaining a balanced development.

Such comparisons can be of assistance to the planners of Pakistan in setting their future growth targets. A target value can be estimated for any indicator by averaging values for all countries (a) with a relatively higher M.D., and (b) located within the same cluster. The target values then can be compared with the actual values. If data are available, the same analysis can be extended to make comparisons between different provinces or districts of Pakistan, which may be useful for planning at micro level.

The quantitative analysis of development reported in this paper may also help the planners of Pakistan in estimating the missing data (particularly for the indicators weighing more heavily in the similar measure), forecasting, and determining the country's foreign-aid requirement. All these proposed exercises are, however, based on a simple averaging concept.

${ }^{4}$ The programme is called GROUPER and is available with the Division of computing Research, C.S.I.R.O., Australia. The programme along with MULCLAS is held in a permanent file named TAXON and can be called down from any C.S.I.R.O. terminal. For details, see Milne $[15]$.

Table 1

Measures and Ranks of Third World Countries on Composite Social, Economic and Socioeconomic Indices of Development

\begin{tabular}{|c|c|c|c|c|c|c|}
\hline \multirow{2}{*}{ Countries } & \multicolumn{2}{|c|}{ Social } & \multicolumn{2}{|c|}{ Economic } & \multicolumn{2}{|c|}{ Socioeconomic } \\
\hline & $(\mathrm{MD})_{\mathrm{s}}$ & Rank & $(\mathrm{MD})_{\mathrm{e}}$ & Rank & $(\mathrm{MD})_{\mathrm{se}}$ & Rank \\
\hline Singapore & 0.6820 & 6 & 0.7886 & 1 & 0.6828 & 1 \\
\hline Israel & 0.6354 & 1 & 0.8101 & 5 & 0.6830 & 2 \\
\hline Puerto Rico & 0.6478 & 2 & 0.8015 & 3 & 0.6847 & 3 \\
\hline Hong Kong & 0.6607 & 4 & 0.8134 & 6 & 0.6980 & 4 \\
\hline Argentina & 0.6483 & 3 & 0.8761 & 14 & 0.7419 & 5 \\
\hline Trinidad Tobago & 0.7296 & 11 & 0.8275 & 7 & 0.7424 & 6 \\
\hline Cyprus & 0.6843 & 7 & 0.8587 & 11 & 0.7452 & 7 \\
\hline Kuwait & 0.8079 & 26 & 0.8001 & 2 & 0.7591 & 8 \\
\hline Lebanon & 0.7311 & 12 & 0.8472 & 10 & 0.7601 & 9 \\
\hline Uruguay & 0.6614 & 5 & 0.8025 & 4 & 0.7656 & 10 \\
\hline Guyana & 0.7467 & 15 & 0.8332 & 8 & 0.7749 & 11 \\
\hline Venezuela & 0.7138 & 10 & 0.8865 & 17 & 0.7799 & 12 \\
\hline Cuba & 0.6855 & 8 & 0.9015 & 22 & 0.7806 & 13 \\
\hline Panama & 0.7443 & 14 & 0.8746 & 12 & 0.7884 & 14 \\
\hline Costa Rica & 0.7672 & 16 & 0.8833 & 16 & 0.8046 & 15 \\
\hline Jamaica & 0.7782 & 20 & 0.8758 & 13 & 0.8059 & 16 \\
\hline Korea, Rep. & 0.7712 & 17 & 0.8815 & 15 & 0.8063 & 17 \\
\hline Libya & 0.8375 & 38 & 0.8458 & 9 & 0.8084 & 18 \\
\hline Chile & 0.6902 & 9 & 0.9335 & 63 & 0.8115 & 19 \\
\hline Mongolia & 0.7428 & 13 & 0.9076 & 27 & 0.8131 & 20 \\
\hline Fiji & 0.7808 & 21 & 0.8983 & 20 & 0.8230 & 21 \\
\hline Mexico & 0.7777 & 19 & 0.9045 & 25 & 0.8262 & 22 \\
\hline Mauritius & 0.7823 & 22 & 0.9110 & 30 & 0.8312 & 23 \\
\hline Brazil & 0.7904 & 23 & 0.9117 & 31 & 0.8353 & 24 \\
\hline Malaysia & 0.8145 & 29 & 0.9002 & 21 & 0.8400 & 25 \\
\hline Peru & 0.7938 & 24 & 0.9240 & 46 & 0.8478 & 26 \\
\hline Nicaragua & 0.8107 & 27 & 0.9122 & 33 & 0.8482 & 27 \\
\hline Gabon & 0.8395 & 39 & 0.8944 & 19 & 0.8495 & 28 \\
\hline Turkey & 0.8005 & 25 & 0.9202 & 41 & 0.8497 & 29 \\
\hline Paraguay & 0.7762 & 18 & 0.9351 & 64 & 0.8502 & 30 \\
\hline
\end{tabular}


Appendix Table $1-($ Contd. $)$

\begin{tabular}{|c|c|c|c|c|c|c|}
\hline \multirow{2}{*}{ Countries } & \multicolumn{2}{|c|}{ Social } & \multicolumn{2}{|c|}{ Economic } & \multicolumn{2}{|c|}{ Socioeconomic } \\
\hline & $(\mathrm{MD})_{\mathrm{s}}$ & Rank & $(\mathrm{MD})_{\mathrm{e}}$ & Rank & $(\mathrm{MD})_{\mathrm{se}}$ & Rank \\
\hline El Salvador & 0.8120 & 28 & 0.9191 & 39 & 0.8541 & 31 \\
\hline Tunisia & 0.8415 & 42 & 0.9017 & 23 & 0.8547 & 32 \\
\hline Syria & 0.8294 & 35 & 0.9093 & 29 & 0.8550 & 33 \\
\hline Iran & 0.8441 & 44 & 0.9023 & 24 & 0.8556 & 34 \\
\hline Dominican Rep. & 0.8263 & 33 & 0.9141 & 34 & 0.8566 & 35 \\
\hline Saudi Arabia & 0.8704 & 59 & 0.8886 & 18 & 0.8579 & 36 \\
\hline Colombia & 0.8201 & 32 & 0.9199 & 40 & 0.8580 & 37 \\
\hline Egypt & 0.8167 & 31 & 0.9243 & 47 & 0.8592 & 38 \\
\hline Bolivia & 0.8296 & 36 & 0.9146 & 35 & 0.8593 & 39 \\
\hline Iraq & 0.8523 & 46 & 0.9084 & 28 & 0.8619 & 40 \\
\hline Ecuador & 0.8166 & 30 & 0.9287 & 56 & 0.8632 & 41 \\
\hline Philippines & 0.8278 & 34 & 0.9334 & 62 & 0.8711 & 42 \\
\hline Honduras & 0.8321 & 37 & 0.9306 & 57 & 0.8727 & 43 \\
\hline Sri Lanka & 0.8404 & 40 & 0.9317 & 60 & 0.8758 & 44 \\
\hline Jordan & 0.8685 & 56 & 0.9120 & 32 & 0.8760 & 45 \\
\hline Botswana & 0.8717 & 62 & 0.9271 & 26 & 0.8775 & 46 \\
\hline Thailand & 0.8430 & 43 & 0.9311 & 58 & 0.8785 & 47 \\
\hline Yemen, P.D.R. & 0.8659 & 54 & 0.9232 & 43 & 0.8799 & 48 \\
\hline Morocco & 0.8607 & 49 & 0.9220 & 42 & 0.8805 & 49 \\
\hline Zambia & 0.8608 & 50 & 0.9258 & 50 & 0.8815 & 50 \\
\hline Ivory Coast & 0.8716 & 61 & 0.9173 & 36 & 0.8829 & 51 \\
\hline Papua New Guinea & 0.8413 & 41 & 0.9407 & 72 & 0.8834 & 52 \\
\hline Liberia & 0.8586 & 47 & 0.9254 & 49 & 0.8835 & 53 \\
\hline Algeria & 0.8722 & 63 & 0.9190 & 38 & 0.8836 & 54 \\
\hline Ghana & 0.8591 & 48 & 0.9282 & 55 & 0.8839 & 55 \\
\hline Senegal & 0.8449 & 45 & 0.9408 & 73 & 0.8858 & 56 \\
\hline Congo & 0.8724 & 64 & 0.9239 & 45 & 0.8867 & 57 \\
\hline Guatemala & 0.8698 & 58 & 0.9269 & 53 & 0.8874 & 58 \\
\hline Angola & 0.8694 & 57 & 0.9263 & 51 & 0.8875 & 59 \\
\hline Cameroon & 0.8676 & 55 & 0.9332 & 61 & 0.8915 & 60 \\
\hline Gambia & 0.8816 & 70 & 0.9272 & 54 & 0.8936 & 61 \\
\hline Sierra Leone & 0.8817 & 71 & 0.9251 & 48 & 0.8940 & 62 \\
\hline Indonesia & 0.8641 & 53 & 0.9406 & 71 & 0.8952 & 63 \\
\hline Madagascar & 0.8625 & 52 & 0.9422 & 75 & 0.8956 & 64 \\
\hline Zaire & 0.8760 & 65 & 0.9365 & 66 & 0.8977 & 65 \\
\hline
\end{tabular}

Appendix Table $1-($ Contd )

\begin{tabular}{|c|c|c|c|c|c|c|}
\hline \multirow{2}{*}{ Countries } & \multicolumn{2}{|c|}{ Social } & \multicolumn{2}{|c|}{ Economic } & \multicolumn{2}{|c|}{ Socioeconomic } \\
\hline & $(\mathrm{MD})_{\mathrm{s}}$ & Rank & $(\mathrm{MD})_{\mathrm{e}}$ & Rank & $(\mathrm{MD})_{\mathrm{se}}$ & Rank \\
\hline Benin & 0.8928 & 83 & 0.9268 & 52 & 0.8978 & 66 \\
\hline Lesotho & 0.8715 & 60 & 0.9398 & 69 & 0.8980 & 67 \\
\hline Mauritania & 0.9024 & 90 & 0.9186 & 37 & 0.8993 & 68 \\
\hline Kenya & 0.8769 & 66 & 0.9397 & 68 & 0.9007 & 69 \\
\hline Central Afr. Rep. & 0.9009 & 89 & 0.9236 & 44 & 0.9016 & 70 \\
\hline Pakistan & 0.8941 & 84 & 0.9312 & 59 & 0.9020 & 71 \\
\hline Togo & 0.8885 & 77 & 0.9359 & 65 & 0.9035 & 72 \\
\hline Nigeria & 0.8835 & 73 & 0.9401 & 70 & 0.9037 & 73 \\
\hline Malawi & 0.8861 & 75 & 0.9390 & 67 & 0.9047 & 74 \\
\hline India & 0.8823 & 72 & 0.9411 & 74 & 0.9057 & 75 \\
\hline Tanzania & 0.8799 & 69 & 0.9436 & 76 & 0.9077 & 76 \\
\hline Burma & 0.8620 & 51 & 0.9585 & 88 & 0.9085 & 77 \\
\hline Sudan & 0.8785 & 67 & 0.9502 & 80 & 0.9087 & 78 \\
\hline Mozambique & 0.8893 & 78 & 0.9459 & 77 & 0.9110 & 79 \\
\hline Laos & 0.8899 & 80 & 0.9499 & 79 & 0.9134 & 80 \\
\hline Haiti & 0.8837 & 74 & 0.9535 & 82 & 0.9167 & 81 \\
\hline Uganda & 0.8869 & 76 & 0.9578 & 87 & 0.9183 & 82 \\
\hline Guinea & 0.8894 & 79 & 0.9553 & 84 & 0.9211 & 83 \\
\hline Mali & 0.8998 & 86 & 0.9527 & 81 & 0.9243 & 84 \\
\hline Somalia & 0.9060 & 91 & 0.9495 & 78 & 0.9255 & 85 \\
\hline Burundi & 0.8918 & 81 & 0.9607 & 89 & 0.9261 & 86 \\
\hline Kampuchea & 0.8786 & 68 & 0.9722 & 96 & 0.9282 & 87 \\
\hline Afghanistan & 0.9098 & 92 & 0.9536 & 83 & 0.9304 & 88 \\
\hline Rwanda & 0.8962 & 85 & 0.9641 & 92 & 0.9307 & 89 \\
\hline Vietnam Soc. Rep. & 0.8924 & 82 & 0.9739 & 97 & 0.9324 & 90 \\
\hline Ethiopia & 0.9006 & 88 & 0.9618 & 91 & 0.9332 & 91 \\
\hline Niger & 0.9005 & 87 & 0.9610 & 90 & 0.9334 & 92 \\
\hline Upper Volta & 0.9191 & 93 & 0.9571 & 86 & 0.9363 & 93 \\
\hline Chad & 0.9309 & 94 & 0.9563 & 85 & 0.9428 & 94 \\
\hline Yemen, A. R. & 0.9321 & 95 & 0.9670 & 93 & 0.9507 & 95 \\
\hline Bangladesh & 0.9358 & 97 & 0.9690 & 94 & 0.9520 & 96 \\
\hline Nepal & 0.9345 & 96 & 0.9696 & 95 & 0.9544 & 97 \\
\hline
\end{tabular}

Note: Countries are listed in descending order of levels of socioeconomic development as reflected by (MD) $\mathrm{se}$ and the corresponding ranks. 
Table 2

\section{LIST OF INDICATORS}

\section{A. Demographic, Social and Political}

\section{Demographic Indicators}

1. Population density per sq. $\mathrm{km}$.

2. Annual rate of growth of population.

3. Percentage of population living in urban areas.

4. Population in localities of 20,000 and over as $\%$ of total population.

5. Average size of private household.

6. Crude birth rate per 1,000 population.

7. Crude death rate per 1,000 population.

8. Infant mortality rate.

9. Expectation of life at birth (average of male and female).

10. Dependency ratio (children aged under 15 plus persons aged 65 and over as $\%$ of the age groups $15-65$ ).

11. Child dependency ratio (children aged under 15 as $\%$ of the age group 15-64).

12. Crude marriage rate per 1,000 population.

13. Crude divorce rate per 1,000 population.

\section{Health and Nutritional Indicators}

14. Hospital beds per 10,000 population.

15. Doctors per 10,000 population

16 Dentists per 10,000 population.

17. Pharmacists per 10,000 population.

18. Nurses per 10,000 population.

19. Midwifery personnel per 10,000 population.

20. Death rate due to infectious and parasitic diseases per 100,000 population.

21. Dietary energy supply per capita daily kilo-calories.

22. Grams protein consumed per capita per day.

23. Total calorie consumption as $\%$ of requirement.

24. \% contribution of animal protein to total intake of protein.

25. Consumption of calories derived from cereals and starchy roots as \% of total calories consumed.

\section{Educational Indicators}

26. Percentage of literacy of adult population (15 plus).

27. Percentage of female literacy ( 15 plus female population).

28. First level enrollment ratio (as \% of the age group 5-14).

29. Second level enrollment ratio (as \% of the age group 15-19).

30. Third level enrollment ratio (as \% of the age group 20-24).

31. $\%$ of females in the first level.

32. \% of females in the second level.

33. $\%$ of females in the third level.

34. Student/teacher ratio (number of students per one teacher) at the first level.

35. Student/teacher ratio (number of students per one teacher) at the second level.

36. Student/teacher ratio (number of students per one teacher) at the third level.

37. Proportion of second level enrollment in vocational education.

38. Proportion of third level enrollment in agricultural courses.

39. Proportion of third level enrollment in medical courses.

40. Proportion of third level enrollment in science and engineering courses.

41. Public expenditure on education as $\%$ of GNP.

42. Total stock of scientists, engineers and technicians per 10,000 population.

43. Total stock of scientists, engineers and technicians engaged in research and experimental development per 10,000 population.

44. Expenditure for research and experimental development as \% of GNP.

45. Production of books (number of titles by subjects per 10,000 population).

\section{Housing Indicators}

46. Average size of dwelling (rooms per dwelling).

47. Average number of persons per room.

48. Dwellings with toilet (and type) as \% of all dwellings.

49. Dwellings with piped water as \% of all dwellings.

50. Dwellings with electricity as $\%$ of all dwellings.

51. Dwellings constructed per 1,000 population.

52. Index number of construction activity $(1970=100)$.

\section{Cultural Indicators}

53. Circulation of daily general-interest newspapers per 1,000 population.

54. Circulation of non-daily general-interest newspapers per 1,000 population.

55. Consumption of newsprint per inhabitant (kilograms).

56. Consumption of printing paper (other than newsprint) and writing paper per inhabitant (kilograms). 
57. Cinema seats per 1,000 population.

58. Annual cinema attendance per inhabitant.

59. Number of radio sets per 1,000 population.

60. Number of T.V. sets per 1,000 population.

\section{Political Indicators}

61. Defence expenditure as $\%$ of GNP.

62. Military personnel per 1,000 population.

63. Voting participation : voter turnout as \% electorate.

64. Political stability index (average tenure of a national executive/ruling group).

65. Death from political violence per one million population.

66. Ethnic and linguistic fractionalization.

\section{B. Economic Indicators}

\section{Agricultural Indicators}

67. $\%$ of total population living on agriculture.

68. Arable land per person in agriculture (hectare/capita).

69. Percentage contribution of agriculture in G.D.P.

70. Index number of per capita total agricultural production $(1961-65=100)$.

71. Use of tractors per 1,000 hectare arable land.

72. Use of chemical fertilizers per 1,000 hectare arable land (in metric tons).

\section{Industry}

73. Index of industrial production (general index, 1970 $=100$ ).

74. \% of total economically active population engaged in industrial activity.

75. \% contribution of industrial activity in G.D.P.

76. \% contribution of manufacturing in G.D.P.

77. Per capita energy consumption (total commercial energy) in kilograms per capita.

78. Per capita electricity consumption (total industrial and public) in kwh.

79. Per capita steel consumption (kilograms/capita).

\section{Labour}

80. \% of total population economically active.

81. \% of females in total economically active population.

82. Share of non-agricultural population in total economically active population.

83. Salaried and wage-earners as \% of total economically active population.

84. General level of unemployment.

85. Degree of industrial unrest (total working days lost as a \% of total economically active population in industrial activity).

\section{Transport and Communications}

86. \% of economically active population engaged in transport, storage and communications.

87. Passenger railway kilometers per capita.

88. Railway net ton kilometers per capita.

89. Motor vehicles (passenger and commercial) per 1,000 population.

90. Total road network per 100 population.

91. \% of roads paved.

92. Civil aviation: passenger $\mathrm{km}$ per capita.

93. Civil aviation: total ton-km per capita.

94. International tourist travel: tourist receipts per capita (in U.S. dollars).

95. Domestic mail (received and sent) per capita.

96. Foreign mail (received and sent) per capita.

97. Domestic telegram (sent) per capita.

98. Foreign telegram (sent) per capita.

99. Number of telephones per 100 population.

\section{V.International Trade}

100. Total value of exports per capita (in U.S. dollars).

101. Total value of imports per capita (in U.S. dollars).

102. Exports as \% of GNP.

103. Imports as \% of GNP.

104. Average annual growth rate of exports.

105. \% contribution of agriculture in total value of exports.

106. \% of contribution of manufacturing in total value of exports.

107. Exports concentration index.

108. Exports diversification index.

109. Index of export fluctuations.

110. Terms of trade (average 1971-75, $1970=100$ ).

\section{General}

111. GNP per capita (at market prices) in U. S. dollars.

112. GNP at parity prices.

113. Annual growth rate of GNP per capita.

114. Government final consumption expenditure as $\%$ of NDP.

115. Private final consumption expenditure as \% of GDP.

116. Gross fixed capital formation as \% of GDP.

117. Total per capita receipt of foreign aid (official development assistance from DAC countries through bilateral institutions U. S. dollars).

118. Total per capita receipt of foreign capital (direct investment and other long term private capital in SDRs).

119. Annual rate of inflation (average for 1971-75)

120. Gini index of income inequality. 


\section{REFERENCES}

1. Adelman, I., M. Geier, and C. T. Morris. "Instruments and Goals in Economic Development.” American Economic Review. Vol. 59. 1969. pp 409-426.

2. Adelman, I., and C. T. Morris. "An Econometric Model of Socio-Economic and Political Change in Underdeveloped Countries". American Economic Review. Vol. 58. 1968. pp 1184-1218.

3. Adelman, I., and C. T. Morris. "A Factor Analysis of the Inter-relationship Between Social and Political Variables and Per Capita Gross National Product." Quarterly Journal of Economics. Vol. 79. 1965. pp. 555-578.

4. Adelman, I., and C. T. Morris. "Performance Criteria for Evaluating Economic Development Potential: An Operational Approach". Quarterly Journal of Economics. Vol. 82. 1968. pp. 260-280.

5. Adelman, I., and C. T. Morris. Society, Politics, and Economic Development A Quantitative Approach. Baltimore: The John Hopkins Press. 1967.

6. Anderberg, M. R. Cluster Analysis for Applications. New York: Academic Press. 1973.

7. Chenery, H. B., and M. Syrquin, Patterns of Development: 1950-1970. London: Oxford University Press. 1975.

8. Harbison, F. H., Joan Maruhnic, and J. R. Resnick. Quantitative Analysis of Modernization and Development. Princeton, N. J.: Princeton University Press. 1970.

9. Khan, M. H. Socio-economic Data Bank. Sydney: The University of New South Wales Libraries. (Mierofiche) 1978.

10. Khan, M. H. "Measuring Socio-economic Development: A Cluster Analytic Approach”. ANZAAS Papers (49th Congress: Auckland). 1979.

11. Khan, M. H. "International Comparisons of Socio-economic Development: A Quantitative Approach". Unpublished Ph. D. dissertation, The University of New South Wales, Sydney. 1979.

12. Khan, M. H. "A Comparative Study of Socio-economic Development: Asia”. Forthcoming in Asian Profile, April. 1981.

13. Khan, M. H., and J. A. Zerby. "A Comparative Study of Socio-economic Development in Latin America". Forthcoming in Social and Economic Studies, June 1982.

14. McGranahan, D. V., and others. Contents and Measurement of Socio-economic Development. New York: Praeger Publishers. 1972. (A U.N.R.I.S.D. staff study)

15. Milne, P.W. "The Canberra Programs and their Accession”. In W. T. Williams (ed.), Pattern Analysis in Agricultural Science. Melbourne: C.S.I.R.O. 1976. pp. 116-123.

16. Sneath, P. H. A., and R. R. Sokal. Numerical Taxonomy. San Francisco: W. H. Freeman \& Co. 1973.
17. Szczepanik, E. F. Agricultural Policies at Different levels of Development. Rome: F.A.O. 1975.

18. U. N. Report of the Working Party on Social Development and Report of the Expert Group on Social Development. New York. 1971. (Sales no. E. 72. II F.7).

19. U.N.E.S.C.O. Social Indicators: Problems of Definition and of Selection. Paris. 1974. (Report No. 30)

20. Zerby, J. A., and M. H. Khan. The Application of Cluster Analysis to Socioeconomic Development. Sydney: The University of New South Wales. 1979. No. 45, School of Economics discussion paper. 